\title{
14th European Marine Biology Symposium "Protection of Life in the Sea:" Closing address
}

\author{
O. Kinne \\ Biologische Anstalt Helgoland (Zentrale); \\ Palmaille 9, D-2000 Hamburg 50, Federal Republic of Germany
}

Ladies and Gentlemen,

Colleagues and Friends!

The 14th European Marine Biology Symposium on "Protection of Life in the Sea" has come to an end. Thank you all for coming here and for participating in this meeting. I would especially like to acknowledge the contributions made by the chairmen, the speakers and the two convenors, Drs. M. J. Hameedi and H. Rosenthal. The informal sessions were found stimulating and, in part, provocative by most of the scientists involved. All formal papers, providing they meet our quality requirements and are submitted in time, will be published in our journal "Helgoländer Meeresuntersuchungen".

I would like to thank most cordially all those who helped me with the organization of this symposium: Dr. K. Anger and Herr. J.-K. Holtmann were responsible for the local organization on Helgoland; our ship crews provided seafood; Dr. and Mrs. Uhlig held a party which - together with the reception, the lampion evening and other social events added fun and relaxation to an otherwise extremely busy and exhausting 6-day symposium; H. Witt helped - along with C. Bell, M. Blake, N. Dubilier, A. Heinemann, U. Kersten and I. Schritt - with administrative problems and in the symposium office. All this support, as well as that of numerous unmentioned members of the Biologische Anstalt Helgoland, is much appreciated. Again, for this symposium, thanks are due to the Gemeinde Helgoland with its Town Councillor P. Botter and its Mayor H.-P. Rickmers for continued help and assistance.

I wish you a good trip home and herewith close the 14th European Marine Biology Symposium. 